\title{
EFEKTIVITAS EDUKASI UNTUK MENINGKATKAN PENGETAHUAN MASYARAKAT DALAM PENANGANAN RINITIS ALERGI
}

\author{
Submitted : 30 September 2017 \\ Edited : 19 Desember 2017 \\ Accepted : 29 Desember 2017 \\ Amelia Lorensia ${ }^{1}$, Nina Purnama Sari ${ }^{2}$ \\ ${ }^{1}$ Departemen Farmasi Klinis-Komunitas, Fakultas Farmasi Universitas Surabaya (UBAYA), \\ Jl. Raya Kalirungkut, Surabaya, Indonesia \\ ${ }^{2}$ Program Studi Apoteker, Fakultas Farmasi Universitas Surabaya (UBAYA), \\ Jl. Raya Kalirungkut, Surabaya, Indonesia \\ Email : amelia.lorensia@gmail.com
}

\begin{abstract}
Allergic rhinitis is a common disorder of the breathing that can affect one's productivity and shock. Therefore it is necessary knowledge in self-management to eliminate exposure to allergens that can increase the symptoms of allergic rhinitis. The purpose of this study is to determine the effectiveness of education in improving public knowledge about drugs allergic rhinitis. The research method is experimental pre-sampling with adult sampling through purposive sampling. Measurement of experience conducted for 3 times, ie before getting education (pre test), post-education (post test), and one month after received education (follow up test). The research conducted in May-July 2016, involving 30 people. The results showed that there were significant differences between pre test and post test $(0,000<p(0.05))$ and between pre test and follow-up test $(0.000<p(0,05))$. However, no changes occurred between post test and follow up test. So education is effective in improving public knowledge in the treatment of allergic rhinitis.
\end{abstract}

Keywords : education, knowledge of allergic rhinitis management

\section{PENDAHULUAN}

Prevalensi alergi di Asia bervariasi meningkat kebanyakan di negara berpenghasilan rendah dan menengah, termasuk asma dan rinitis alergi (RA). Prevalensi asma dan AR meningkat di Asia Pasifik dan prevalensi komorbiditas tinggi. Data terakhir menunjukkan tingkat komorbiditas asma dan RA yang sangat tinggi karena $60 \%$ sampai $80 \%$ pasien asma memiliki gejala rhinitis ${ }^{(1)}$. Di dunia, RA mempengaruhi hingga $10-30 \%$ dari total populasi $^{(2)}$. RA merupakan rinitis kronik non infeksius yang paling umum dijumpai, dengan disertai gejala hidung berair, hidung tersumbat, hidung gatal dan bersin. RA didefinisikan sebagai suatu penyakit inflamasi yang dimediasi imunoglobulin $\mathrm{E}$ (IgE) setelah terjadi suatu paparan terhadap membran mukosa hidung oleh alergen tertentu, baik berasal dari indoor maupun outdoor, contohnya tungau, binatang peliharaan, serangga, tumbuhan, serbuk sari, jamur, serta alergen yang terkait tempat kerja $^{(3,4,5)}$. RA dapat menyebabkan berbagai komplikasi seperti sinusitis, polip hidung dan otitis media ${ }^{(6,7)}$. RA bukan penyakit fatal yang menyebabkan kematian, namun gejala yang ditimbulkan penyakit ini sangat mengganggu aktivitas sehari-hari dan dapat berdampak pada penurunan kualitas hidup, bahkan dapat mengganggu aktivitas sosial ${ }^{(4)}$. 
Berdasarkan komplikasi dari RA maka dibutuhkan adanya manajemen rinitis alergi berupa terapi farmakologi dan terapi non farmakologi. Ada beberapa golongan obat untuk pengobatan terapi farmakologi yaitu golongan antihistamin, dekongestan, kortikosteroid, anti-leukotrien (LTRA) dan immunoterapi ${ }^{(6)}$. Semakin meningkatnya kecerdasan masyarakat saat ini, ada kecenderungan untuk melakukan pengobatan sendiri (swamedikasi) untuk penyakit-penyakit ringan tertentu. Swamedikasi adalah upaya seseorang dalam mengobati gejala sakit atau penyakit tanpa berkonsultasi dengan dokter terlebih dahulu $^{(8)}$. Dalam hal ini, apoteker bisa ikut berperan serta mendukung pengobatan swamedikasi ini, karena profesi apoteker dalam pekerjaan kefarmasian untuk meningkatkan kualitas hidup pasien ${ }^{(9)}$. Apoteker bisa memberikan informasi obat yang objektif dan rasional, dengan memberikan bantuan, nasehat dan petunjuk kepada masyarakat yang ingin melakukan swamedikasi, agar dapat melakukannya secara bertanggung jawab ${ }^{(10)}$. Pelayanan farmasi tidak hanya melibatkan terapi obat (realisasi pengadaan obat) tapi juga keputusan tentang obat-obatan yang akan digunakan untuk pasien yang paling tepat, termasuk keputusan untuk tidak menggunakan terapi obat-obatan serta penilaian tentang pilihan pengobatan, dosis, rute, metode administrasi, pemantauan terapi obat dan penyediaan obat-terkait informasi dan konseling kepada pasien ${ }^{(11)}$.

Langkah awal dalam penanganan RA adalah dengan memodififikasi gaya hidup pasien dalam menghindari alergen pemicu RA. Jika tidak dapat menghindari alergen, biasanya digunakan terapi farmakologi membantu meringankan gejala yang muncul $^{(12)}$. Pencegahan dapat berpengaruh pada manajemen diri (self management) masyarakat yaitu proses dimana seseorang mengembangkan keterampilan untuk mengelola kondisi mereka. Perubahan pola hidup menjadi lebih sehat dan kemampuan dalam manajemen diri dapat membantu mengatasi perburukan penyakit seperti asma, ${ }^{(13,14)}$ yang erat kaitannya dengan RA.

Berdasarkan jurnal-jurnal dan penelitian terdahulu belum ada yang membahas mengenai peran apoteker terhadap edukasi mengenai rinitis alergi. Tujuan pemberian konseling kepada pasien adalah untuk mengetahui sejauh mana pengetahuan dan kemampuan pasien dalam menjalani pengobatannya serta untuk memantau perkembangan terapi yang dijalani pasien.

\section{METODE PENELITIAN}

Metode penelitian yang dilakukan dalam penelitian ini adalah eksperimen dengan pendekatan kuantitatif yang bersifat pra-eksperimental. Proses pengambilan data penelitian ini dilakukan pada bulan Mei sampai Juli 2016. Lokasi penelitian berada di sekitar RW 14 (Kecamatan Semampir, Kelurahan Wonokusumo) dan pada saat pelaksanaan edukasi berpusat di di Jln.Wonosari Lor I/79, Kecamatan Semampir, Kelurahan Wonokusumo di Surabaya Utara. Penelitian diadakan ditempat ini dengan alasan belum pernah dilaksanakan edukasi mengenai rinitis alergi sebelumnya.

Variabel dalam penelitian ini adalah variabel bebas yaitu edukasi dan pengetahuan mengenai rinitis alergi (RA). Pengetahuan yang dimaksud dalam penelitian ini adalah pemahaman masyarakat (sampel penelitian) dalam pencegahan upaya mengurangi dan menghindari paparan alergen ataupun pengobatan rinitis alergi mengenai obatnya, tujuan obat, cara penggunaan, serta penggunaan khusus dari obat dan kapan harus merujuk ke dokter.

Edukasi yang dimaksud dalam penelitian ini adalah informasi yang akan diberikan apoteker kepada masyarakat 
(sampel penelitian) dalam pencegahan upaya mengurangi dan menghindari paparan alergen ataupun pengobatan RA mengenai obatnya, tujuan obat, cara penggunaan serta penggunaan khusus dari obat dan kapan harus merujuk ke dokter. Materi edukasi disusun berdasarkan Allergic Rhinitis and its Impact on Asthma (2008) $)^{(3,4)}$ yang merupakan pedoman untuk penatalaksanaan RA. Bentuk edukasi yang dilakukan pada penelitian ini yaitu dengan cara mempersentasikan bahan (materi) RA secara langsung kepada sampel penelitian oleh apoteker dari apotek setempat selaku pembicara. Pengukuran tingkat pengetahuan akan dilakukan sebanyak tiga kali, yaitu sebelum mendapatkan edukasi (pre test), sesaat setelah mendapatkan edukasi (post test), dan satu bulan setelah mendapatkan edukasi (follow-up test).

Populasi dalam penelitian adalah usia dewasa (15-59 tahun $)^{(15)}$ dan sampel penelitian adalah yang bersedia dan menghadiri edukasi. Teknik pengambilan sampel menggunakan purposive sampling. Besar sampel penelitian menggunakan rumus:

$$
n=\frac{z^{2} \cdot p \cdot q}{d^{2}}
$$

$\mathrm{n}=$ besar sampel minimum

$\mathrm{p}=$ proporsi persentase kelompok populasi pertama

$\mathrm{q}=$ proporsi persentase kelompok ke dua / proporsi sisa $=1-\mathrm{p}$

$\mathrm{z}=$ derajat koefisien pada taraf kepercayaan tertentu (pada 95\%, maka $\mathrm{z}=1,960$ )

$\mathrm{d}=$ persentase perkiraan kemungkinan membuat kekeliruan dalam menentukan ukuran sampel sebesar 0,2

Maka besar sampel penelitian minimum adalah 25 orang.
Instrumen yang digunakan pada penelitian ini adalah kuesioner yang telah divalidasi sebelumnya pada 20 orang yang berasal dari tempat berbeda dengan kriteria dan latar belakang yang serupa dengan sampel penelitian. Penelitian ini menggunakan uji distribusi normal yaitu uji untuk mengukur apakah data kita memiliki distribusi normal sehingga dapat dipakai dalam statistik parametrik dengan dinilai menggunakan tes Kolmogorov-Smirnov. Jadi yang dibandingkan adalah frekuensi kumulatif distribusi teoritik dengan frekuensi kumulatif distribusi empirik. Uji perbedaan rerata dengan uji-t berpasangan (Paired samples T-Test) dengan uji dua sisi (Two Tailed atau Two Sides). Tes dilakukan pada eksperimen dan kontrol yaitu berupa test awal (Pre test) dan tes akhir (Post test), dan satu bulan setelah edukasi (follow-up test).

\section{HASIL DAN PEMBAHASAN}

Berdasarkan data yang diperoleh pada saat penyuluhan pertama kali yaitu pre test dan post test terdapat sebanyak 36 orang responden, namun 6 orang diantaranya di drop-out dikarenakan tidak memenuhi kriteria inklusi dikarenakan tidak bisa membaca dan menulis ( 2 orang) dan yang tidak memenuhi kriteria usia yag ditetapkan dalam penelitian (4 orang). Sehingga yang memenuhi kriteria inklusi hanya sebanyak 30 orang.

Tabel 1 menjelaskan tentang jumlah responden berdasarkan karakteristik mencakup jenis kelamin, umur, tingkat pendidikan akhir dan pekerjaan. Kategori umur terbesar pada masa dewasa akhir (3645 tahun) yaitu sejumlah 16 orang $(53,33 \%)$ dan angka terbesar berdasarkan tingkat pendidikan akhir responden yaitu SMA/ SMK sebesar 17 orang $(56,67 \%)$, serta berdasarkan pekerjaan responden terbesar yaitu IRT sejumlah 25 orang $(83,33 \%)$ dan jumlah semua responden berjenis kelamin perempuan sebesar $100 \%$ atau total responden sejumlah 30 orang (Tabel 1). 
Tabel 1. Karakteristik Responden

\begin{tabular}{llcc}
\hline & Karakteristik & $\begin{array}{c}\text { Jumlah } \\
(\mathbf{n}: \mathbf{3 0})\end{array}$ & $\begin{array}{c}\text { Persentase } \\
(\boldsymbol{\%})\end{array}$ \\
\hline \multirow{2}{*}{ Jenis Kelamin } & Laki-laki & 0 & 0 \\
Usia (tahun) & Perempuan & 30 & 100 \\
& Masa dewasa awal (26-35) & 3 & 10,00 \\
\multirow{5}{*}{ Tingkat Pendidikan } & Masa dewasa akhir (36-45) & 16 & 53,33 \\
Akhir & Masa lansia awal (46-55) & 11 & 36,67 \\
& Sekolah dasar (SD) & 7 & 23,33 \\
& Sekolah Menengah Pertama (SMP) & 4 & 13,33 \\
& Sekolah Menengah Atas (SMA) / Sekolah & 17 & 56,67 \\
Pekerjaan & Menengah Kejuruan (SMK) & 1 & 3,33 \\
& Diploma-3 (D3) & 1 & 3,33 \\
& Strata-1 (S1) & 25 & 83,33 \\
& IRT (Ibu Rumah Tangga) & 1 & 3,33 \\
& Karyawan & 4 & 13,33 \\
\hline
\end{tabular}

Tabel 2. Soal Kuesioner Pengetahuan mengenai Rinitis Alergi

\begin{tabular}{|c|c|c|}
\hline $\begin{array}{l}\text { Klasifikasi } \\
\quad \text { Soal }\end{array}$ & $\begin{array}{c}\text { Nomor } \\
\text { Soal }\end{array}$ & Pertanyaan \\
\hline \multirow[t]{5}{*}{ Definisi } & 1 & $\begin{array}{l}\text { Apakah rinitis alergi merupakan reaksi radang yang terjadi akibat } \\
\text { paparan alergen pada mukosa hidung karena sistem kekebalan tubuh } \\
\text { bereaksi secara berlebihan terhadap partikel - partikel yang ada di } \\
\text { udara yang kita hirup? }\end{array}$ \\
\hline & 2 & $\begin{array}{l}\text { Apakah rinitis alergi bukan merupakan reaksi radang setelah terjadi } \\
\text { paparan alergen pada mukosa hidung karena sistem kekebalan tubuh } \\
\text { bereaksi secara berlebihan terhadap alergen? }\end{array}$ \\
\hline & 3 & $\begin{array}{l}\text { Apakah rinitis alergi merupakan reaksi radang pada mukosa hidung } \\
\text { tanpa melibatkan sistem kekebalan tubuh? }\end{array}$ \\
\hline & 4 & $\begin{array}{l}\text { Apakah rinitis alergi bukan merupakan reaksi radang pada mukosa } \\
\text { hidung tanpa melibatkan sistem kekebalan tubuh? }\end{array}$ \\
\hline & 5 & $\begin{array}{l}\text { Apakah rinitis alergi merupakan reaksi radang pada mukosa hidung } \\
\text { dan mata terjadi karena sistem kekebalan tubuh bereaksi secara } \\
\text { berlebihan terhadap alergen? }\end{array}$ \\
\hline \multirow[t]{4}{*}{ Gejala } & 6 & $\begin{array}{l}\text { Apakah gejala yang ditimbulkan oleh rinitis alergi adalah hidung } \\
\text { berair, hidung tersumbat, hidung gatal dan bersin berulang? }\end{array}$ \\
\hline & 7 & $\begin{array}{l}\text { Apakah rinitis alergi ditandai dengan gejala hidung berair, hidung } \\
\text { gatal, bersin dan batuk? }\end{array}$ \\
\hline & 8 & $\begin{array}{l}\text { Apakah rinitis alergi hanya memiliki satu atau dua gejala yang } \\
\text { ditimbulkan? }\end{array}$ \\
\hline & 9 & $\begin{array}{l}\text { Apakah rinitis alergi dapat dikatakan parah dan harus dirujuk ke } \\
\text { dokter apabila penderita terganggu tidurnya dengan bangun setiap } \\
\text { hari pada malam hari dan penyakitnya berlangsung lebih dari } 4 \\
\text { minggu? }\end{array}$ \\
\hline
\end{tabular}




\begin{tabular}{|c|c|c|}
\hline $\begin{array}{l}\text { Klasifikasi } \\
\text { Soal }\end{array}$ & $\begin{array}{c}\text { Nomor } \\
\text { Soal }\end{array}$ & Pertanyaan \\
\hline Gejala & 10 & $\begin{array}{l}\text { Apakah rinitis alergi bukan penyakit fatal yang dapat menyebabkan } \\
\text { kematian tetapi sangat mengganggu kegiatan seahari-hari / sekolah / } \\
\text { pekerjan? }\end{array}$ \\
\hline \multirow[t]{5}{*}{ Penyebab } & 11 & $\begin{array}{l}\text { Apakah serbuk sari dan spora tumbuhan merupakan faktor pemicu } \\
\text { rinitis alergi diluar rumah? }\end{array}$ \\
\hline & 12 & $\begin{array}{l}\text { Apakah rnitis alergi disebabkan oleh faktor yang menjadi pemicu } \\
\text { diluar rumah yaitu serbuk sari dan debu rumah dan asap rokok? }\end{array}$ \\
\hline & 13 & $\begin{array}{l}\text { Apakah debu rumah seperti tungau, serangga, kecoa, spora jamur, } \\
\text { asap rokok dan bulu hewan peliharaan seperti kucing dan anjing } \\
\text { merupakan penyebab rinitis alergi dari faktor pemicu diluar rumah? }\end{array}$ \\
\hline & 14 & $\begin{array}{l}\text { Apakah pemicu rinitis alergi yang didalam rumah adalah debu rumah, } \\
\text { asap rokok, spora tumbuhan dan percikan batuk berdahak? }\end{array}$ \\
\hline & 15 & $\begin{array}{l}\text { Apabila bila salah satu dari faktor pemicu baik diluar ataupun didalam } \\
\text { rumah terpenuhi maka disebut terkena rintis alergi? }\end{array}$ \\
\hline \multirow[t]{5}{*}{ Komplikasi } & 16 & $\begin{array}{l}\text { Apakah apabila rhinitis alergi dibiarkan dan tidak ditangani dengan } \\
\text { baik, maka akan berpotensi mengalami komplikasi seperti sinusitis, } \\
\text { polip hidung dan otitis media? }\end{array}$ \\
\hline & 17 & $\begin{array}{l}\text { Apakah sinusitis merupakan satu-satunya komplikasi yang terjadi } \\
\text { pada rinitis alergi? }\end{array}$ \\
\hline & 18 & $\begin{array}{l}\text { Apakah polip merupakan salah satu jenis penyakit dibagian hidung, } \\
\text { sejenis peradangan dan akhirnya membuat benjolan seperti daging } \\
\text { yang mempunyai cabang di dekat rongga hidung? }\end{array}$ \\
\hline & 19 & $\begin{array}{l}\text { Apakah otitis media dalah infeksi pada telinga bawah, dan anak akan } \\
\text { mengeluhkan nyeri disertai penurunan pendengaran? }\end{array}$ \\
\hline & 20 & Apakah penyebab dari otitis media akut adalah bakteri dan jamur? \\
\hline \multirow{5}{*}{$\begin{array}{l}\text { Tujuan } \\
\text { Pencegahan } \\
\text { dan } \\
\text { Pengobatan }\end{array}$} & 21 & $\begin{array}{l}\text { Apakah rinitis alergi bertujuan untuk mencegah faktor pencetus hanya } \\
\text { didalam rumah saja? }\end{array}$ \\
\hline & 22 & $\begin{array}{l}\text { Apakah rinitis alergi bertujuan untuk mencegah faktor pencetus baik } \\
\text { didalam ataupun diluar? }\end{array}$ \\
\hline & 23 & $\begin{array}{l}\text { Apakah pengobatan rinitis alergi bertujuan untuk mengurangi gejala, } \\
\text { meminimalkan efek samping, meningkatkan produktivitas pasien dan } \\
\text { mencegah komplikasi? }\end{array}$ \\
\hline & 24 & $\begin{array}{l}\text { Apakah pengobatan rinitis alergi bertujuan untuk menghindari faktor } \\
\text { pemicu didalam rumah? }\end{array}$ \\
\hline & 25 & $\begin{array}{l}\text { Apakah pengobatan rinitis alergi bertujuan untuk menyebabkan } \\
\text { komplikasi dan penurunan kualitas hidup? }\end{array}$ \\
\hline \multirow[t]{3}{*}{ Pencegahan } & 26 & $\begin{array}{l}\text { Apakah menghindari serbuk sari, spora yang ada diluar rumah dan } \\
\text { menghindari asap rokok adalah cara untuk mencegah terjadinya rinitis } \\
\text { alergi? }\end{array}$ \\
\hline & 27 & $\begin{array}{l}\text { Apakah menutup hidung apabila melihat bunga adalah cara untuk } \\
\text { mencegah terjadinya rintis alergi yang ada diluar rumah? }\end{array}$ \\
\hline & 28 & $\begin{array}{l}\text { Apakah pencegahan rinitis alergi diluar rumah yaitu dengan } \\
\text { menghindari asap rokok, menggunakan obat flu dan menggunakan } \\
\text { masker setiap keluar? }\end{array}$ \\
\hline
\end{tabular}




\begin{tabular}{|c|c|c|}
\hline $\begin{array}{l}\text { Klasifikasi } \\
\text { Soal }\end{array}$ & $\begin{array}{l}\text { Nomor } \\
\text { Soal }\end{array}$ & Pertanyaan \\
\hline \multirow[t]{7}{*}{ Pencegahan } & 29 & $\begin{array}{l}\text { Apakah untuk mencegah terjadinya rinitis alergi yaitu dengan } \\
\text { menghindari spora dan jamur yang ada diluar rumah serta } \\
\text { menghindari asap rokok? }\end{array}$ \\
\hline & 30 & $\begin{array}{l}\text { Apakah untuk mencegah terjadinya rinitis alergi yaitu dengan tidak } \\
\text { berinteraksi dengan orang lain diluar rumah? }\end{array}$ \\
\hline & 31 & $\begin{array}{l}\text { Apakah pencegahan rinitis alergi didalam rumah yaitu dengan cara } \\
\text { menghindari bulu kucing dan anjing, menutup jendela, membersihkan } \\
\text { debu, membersihkan karpet yang berdebu, membersihkan bantal dan } \\
\text { guling yang berdebu serta menghindari asap rokok? }\end{array}$ \\
\hline & 32 & $\begin{array}{l}\text { Apakah pencegahan rinitis alergi didalam rumah yaitu dengan cara } \\
\text { menghindari bulu kucing dan anjing serta bulu burung? }\end{array}$ \\
\hline & 33 & $\begin{array}{l}\text { Apakah untuk mencegah rinitis alergi yang ada didalam rumah salah } \\
\text { satunya dengan cara selalu membersihkan debu rumah? }\end{array}$ \\
\hline & 34 & $\begin{array}{l}\text { Apakah untuk mencegah terjadinya rinitis alergi masyarakat harus } \\
\text { menggunakan obat? }\end{array}$ \\
\hline & 35 & $\begin{array}{l}\text { Apakah dengan tidak menggunakan karpet yang berdebu dan } \\
\text { menghindari asap rokok merupakan pencegahan dari rinitis alergi? }\end{array}$ \\
\hline \multirow[t]{10}{*}{ Pengobatan } & 36 & $\begin{array}{l}\text { Apakah pasien yang terkena rinitis alergi maka membutuhkan } \\
\text { pengobatan? }\end{array}$ \\
\hline & 37 & $\begin{array}{l}\text { Apakah obat yang digunakan pada pasien rinitis alergi golongan } \\
\text { antihistamin atau obat alergi yang menimbulkan kantuk yaitu CTM ? }\end{array}$ \\
\hline & 38 & $\begin{array}{l}\text { Apakah obat yang digunakan pada pasien rinitis alergi golongan } \\
\text { antihistamin atau obat alergi yang menimbulkan kantuk yaitu CTM } \\
\text { dan cetirizine? }\end{array}$ \\
\hline & 39 & $\begin{array}{l}\text { Apakah cetirizine merupakan obat yang digunakan untuk alergi tanpa } \\
\text { menyebabkan kantuk? }\end{array}$ \\
\hline & 40 & $\begin{array}{l}\text { Apakah loratadine merupakan obat yang tepat pada pasien yang tidak } \\
\text { menginginkan efek kantuk sehingga dapat melanjutkan aktivitas } \\
\text { bekerja maupun pengendara? }\end{array}$ \\
\hline & 41 & $\begin{array}{l}\text { Apakah pada pasien rinitis alergi menggunakan obat golongan } \\
\text { dekongestan atau pelega hidung? }\end{array}$ \\
\hline & 42 & $\begin{array}{l}\text { Apakah pseudoefedrin merupakan pilihan obat yang tepat pada pasien } \\
\text { rintis alergi yang tidak menginginkan efek kantuk dan sudah termasuk } \\
\text { gabungan dari obat alergi dan pelega hidung? }\end{array}$ \\
\hline & 43 & $\begin{array}{l}\text { Apakah paracetamol sebagai analgesik merupakan obat yang } \\
\text { digunakan untuk alergi? }\end{array}$ \\
\hline & 44 & $\begin{array}{l}\text { Apakah asam mefenamat merupakan obat golongan pelega hidung } \\
\text { untuk pasien rinitis alergi? }\end{array}$ \\
\hline & 45 & $\begin{array}{l}\text { Apakah amoksisilin (antibiotik) dapat digunakan untuk pengobatan } \\
\text { rinitis alergi? }\end{array}$ \\
\hline
\end{tabular}


Berdasarkan klasifikasi soal rinitis alergi dari hasil ketiga kali tes (Tabel 2), menunjukkan bahwa sebagian besar hasil post-test menunjukkan peningkatan dibandingkan dengan pre-test, walaupun ada yang mengalami nilai yang tetap (nomor: 20) namun tidak ada yang mengalami penurunan poin. Sedangkan pada follow-up test menunjukkan sebagian besar klasifikasi soal mengalami peningkatan nilai atau tetap dibandingkan post test, namun ada beberapa poin yang mengalami penurunan dibandingkan dengan post test (nomor: 2, 9, 12, dan 18).

Tabel 3 menjelaskan tentang jumlah responden yang mendapatkan tes pengetahuan dimana ada perbedaan antara pre test (sebelum diberikan edukasi), post test (setelah diberikan edukasi), dan followup test (satu bulan setelah pemberian edukasi). Rata-rata total nilai tes tertinggi berada pada follow-up test $(14,43)$ dibandingkan dengan rata-rata post test $(13,90)$ dan pre test $(7,23)$, serta terjadi peningkatan rata-rata total nilai tes dari awal pre test kemudian post test dan terakhir adalah follow-up test. Ada peningkatan ratarata total nilai tes dari awal pre test kemudian post test dan terakhir adalah follow-up test, berupa perubahan nilai total sebelum (pre test) dan sesudah edukasi (post test) mengalami peningkatan sebesar $100 \%$ (30 sampel), yang berarti semua responden mengalami peningkatan nilai total. Data pengetahuan setelah edukasi (post test) dibandingkan follow-up test maka ada penurunan sebanyak 8 orang responden dan hanya ada peningkatan pada 15 orang. Namun bila nilai total follow-up test dibandingkan dengan pre test (baseline) maka tetap menunjukkan peningkatan sebesar 29 orang $(96,67 \%)$.

Tabel 4 menunjukkan bahwa perubahan terbesar terlihat antara hasil follow-up dibandingkan dengan pre test. Hal ini menunjukkan bahwa setelah 1 bulan dari pemberian edukasi namun responden tetap mengingat informasi yang diberikan pada saat edukasi bahkan perubahannya lebih tinggi bila dibandingkan antara post test yang langsung diberikan setelah edukasi. Perubahan terbesar adalah dari pre test ke follow-up test, dimana semua soal mengalami peningkatan. Nilai total tingkat pengetahuan RA berdasarkan kelompok yang dibandingkan, maka disimpulkan pre test ke post test memiliki nilai $\mathrm{p}(0,00)>0,05$ artinya ada perbedaaan signifikan. Kelompok pre test ke follow-up test memiliki nilai $\mathrm{p}(0,00)<0,05$ artinya ada perbedaan signifikan. Kelompok post test ke follow-up test memiliki nilai $\mathrm{p}(0,265)<0,05$ artinya tidak ada perbedaan signifikan.

Tabel 5 menyatakan bahwa ketiga tes data memiliki distribusi normal karena memiliki sig. diatas alpha $0,05 \quad(>0,05)$. Hasil penelitian menunjukkan bahwa ada perbedaan signifikan antara pre test dengan post test $(0,000<\mathrm{p}(0,05))$ yang berarti ada peningkatan yang signifikan setelah pemberian edukasi. Dan ada perbedaan yang signifikan antara pre test dan follow-up test $(0,000<\mathrm{p}(0,05)) \quad$ yang berarti ada peningkatan yang signifikan setelah satu bulan sejak diberikan edukasi. Namun tidak ada perubahan signifikan terjadi antara post test dengan follow-up test (Tabel 6). 
Tabel 3. Distribusi Frekuensi Total Nilai Tes dan Klasifikasi Tingkat Pengetahuan Mengenai Rinitis Alergi

\begin{tabular}{|c|c|c|c|c|c|c|}
\hline \multirow{3}{*}{$\begin{array}{c}\text { Tingkat } \\
\text { Pengetahuan } \\
\text { Rinitis Alergi }\end{array}$} & \multicolumn{6}{|c|}{ Jumlah Responden yang mendapatkan Tes Pengetahuan (n:30) } \\
\hline & \multicolumn{2}{|c|}{ Pre Test } & \multicolumn{2}{|c|}{ Post Test } & \multicolumn{2}{|c|}{ Follow-up Test } \\
\hline & $\Sigma$ & $\begin{array}{c}\text { Persentas } \\
\text { e }(\%)\end{array}$ & $\Sigma$ & $\begin{array}{c}\text { Persentas } \\
\text { e }(\%)\end{array}$ & $\Sigma$ & $\begin{array}{c}\text { Persenta } \\
\text { e }(\%)\end{array}$ \\
\hline Tinggi $(>50 \%)$ & 3 & 10,00 & 29 & 96,67 & 25 & 83,33 \\
\hline Sedang $(=50 \%)$ & 0 & 0 & 1 & 3,33 & 3 & 10,00 \\
\hline Rendah $(<50 \%)$ & 27 & 90,00 & 0 & 0 & 2 & 6,67 \\
\hline
\end{tabular}

Keterangan:

Tinggi ( $>50 \%)$ : responden dapat menjawab soal dengan benar hingga $>50 \%$ dari soal (dapat menjawab minimal 24 soal dengan benar)

Sedang $(=50 \%)$ : responden dapat menjawab sebagian soal dengan benar sebesar $50 \%$ dari soal (dapat menjawab sebanyak 23 soal dengan benar)

Rendah $(<50 \%)$ : responden dapat menjawab sebagian soal dengan benar sebesar $>50 \%$ dari soal (dapat menjawab maksimal 22 soal dengan benar)

Tabel 4. Distribusi Frekuensi Rata-rata Perubahan Nilai Total Tingkat Pengetahuan Responden

\begin{tabular}{lccc}
\hline & \multicolumn{3}{c}{$\begin{array}{c}\text { Perubahan Tingkat Pengetahuan Berdasarkan Waktu } \\
\text { Pemberian Kepada Responden }\end{array}$} \\
\cline { 2 - 4 } & $\begin{array}{c}\text { Pre Test ke } \\
\text { Post } \text { Test }\end{array}$ & $\begin{array}{c}\text { Pre Test ke } \\
\text { Follow-up } \text { Test }\end{array}$ & $\begin{array}{c}\text { Post } \text { Test ke } \\
\text { Follow-up } \text { Test }\end{array}$ \\
\hline $\begin{array}{l}\text { Rata-rata Perubahan Nilai } \\
\text { Total Tingkat Pengetahuan } \\
\text { Responden }\end{array}$ & 6,67 & 7,20 & 0,53 \\
\hline
\end{tabular}

Tabel 5. Uji Normalitas Data Nilai Total Pengetahuan Responden

\begin{tabular}{cccc}
\hline & \multicolumn{3}{c}{ Nilai P dari Uji Kolmogorov-Smirnov } \\
\cline { 2 - 4 } & Pre Test & Post Test & Follow-Up Test \\
\hline Nilai P & 0,318 & 0,230 & 0,484 \\
\hline Kesimpulan & Normal & Normal & Normal \\
\hline
\end{tabular}


Tabel 6. Uji Perbedaan Nilai Total Tingkat Pengetahuan Rinitis Alergi Menggunakan uji t-test Berpasangan

\begin{tabular}{cccc}
\hline & \multicolumn{2}{c}{ Nilai P dari Uji T-Test Berpasangan } \\
\cline { 2 - 4 } & $\begin{array}{c}\text { Pre Test ke } \\
\text { Post Test }\end{array}$ & $\begin{array}{c}\text { Pre Test ke } \\
\text { Follow-up Test }\end{array}$ & $\begin{array}{c}\text { Post Test ke } \\
\text { Follow-up Test }\end{array}$ \\
\hline Uji Statistik & $-12,226$ & $-11,676$ & $-1,137$ \\
\hline Skala & Rasio & Rasio & Rasio \\
\hline Nilai P & 0,000 & 0,000 & 0,265 \\
\hline Kesimpulan & $\begin{array}{c}\text { Ada perbedaan } \\
\text { signifikan }\end{array}$ & $\begin{array}{c}\text { Ada perbedaan } \\
\text { signifikan }\end{array}$ & $\begin{array}{c}\text { Tidak ada } \\
\text { perbedaan } \\
\text { signifikan }\end{array}$ \\
\hline
\end{tabular}

Peran tenaga kesehatan masyarakat terutama apoteker bertujuan untuk menyediakan pelayanan kefarmasian secara langsung, bertanggungjawab terhadap persedian terkait pengobatan dengan tujuan untuk meningkatkan kualitas hidup pasien. Pelayanan farmasi tidak hanya melibatkan terapi obat (realisasi pengadaan obat) tapi juga keputusan tentang obat-obatan yang akan digunakan untuk pasien yang paling tepat, termasuk keputusan untuk tidak menggunakan terapi obat-obatan serta penilaian tentang pilihan pengobatan, dosis, rute dan metode administrasi, pemantauan terapi obat, dan penyediaan obat-terkait informasi dan konseling kepada pasien ${ }^{(11)}$.

Rentang waktu yang digunakan pada saat follow-up test yaitu selama satu bulan, karena lamanya waktu tersebut tidak terlalu jauh dari penelitian. Tujuan dilakukannya follow-up adalah untuk mengetahui apakah informasi yang diberikan saat edukasi mengalami perubahan atau tidak. Hal-hal yang bisa mempengaruhi hasil follow-up, antara lain:

a. Ingatan. Ingatan akan sangat mempengaruhi pengetahuan seseorang, sehingga makin lama suatu informasi diberikan maka akan menyebabkan seseorang cenderung lupa.

b. Namun tidak selalu follow-up akan memberikan hasil yang lebih rendah dibandingkan saat setelah memberikan informasi (edukasi), karena ada kemungkinan pula partisipan berdiskusi bersama teman-temannya dan saling bertukar informasi. Hal ini juga dapat meningkatkan pengetahuan dan pemahaman seseorang terhadap informasi yang baru saja di dapatkannya.

c. Perubahan perilaku. Informasi yang diterapkan menjadi suatu kebiasaan akan membuat seseorang lebih paham dan lebih banyak informasi yang di dapatkannya.

Penelitian terdahulu oleh Laliberté et al. (2012), sebanyak 571 dari 1.234 (46,3\%) orang yang memenuhi syarat apoteker komunitas di Quebec, Canada, bahwa sebagian percaya bahwa apoteker harus sangat terlibat dalam promosi kesehatan dan pencegahan, khususnya di berhenti merokok $(84,3 \%)$; skrining untuk hipertensi $(81,8 \%)$, diabetes $(76,0 \%)$ dan dislipidemia $(56,9 \%)$; dan kesehatan seksual $(61,7 \%$ ke $89,1 \%)$; Namun, lebih sedikit responden melaporkan benar-benar berada sangat terlibat dalam 
menyediakan layanan tersebut $(5,7 \%$ [gaya hidup, termasuk berhenti merokok], 44,5\%, $34,8 \%, 6,5 \%$ dan $19,3 \%$, masing-masing $)^{(16)}$. Hambatan utama untuk penyediaan layanan ini dalam praktek saat ini adalah kurangnya: waktu $(86,1 \%)$, koordinasi dengan para profesional lain perawatan kesehatan $(61,1 \%)$, staf atau sumber daya $(57,2 \%)$, kompensasi finansial $(50,8 \%)$, dan klinis alat $(45,5 \%)$. Prioritas edukasi kesehatan selama ini adalah pada penyakit-penyakit kronis dan bukan pada pencegahan berupa perubahan gaya hidup.

Dalam penyusunan kuesioner peneliti menggunakan blueprint yang sudah memetakan (mengklasifikasikan) pengetahuan yang diperlukan oleh responden terkait AR. Pada blue print, terlihat komposisi pada poin pencegahan dan pengobatan relatif lebih tinggi dibandingkan topik lainnya, karena dengan responden memiliki pengetahuan dalam pencegahan dan pengobatan maka mereka sudah memahami aplikasi dari pengetahuan topik lainnya. Namun karena tujuan dari penelitian ini masih bersifat pemahaman saja sehingga tidak mengukur bagaimana aplikasi informasi tersebut terkait dengan perubahan kebiasaan dan sikap.

Keterbatasan penelitian ini adalah:

a. Keterbatasan dari penelitian saat ini adalah jumlah sampel yang terbatas. Dengan demikian sampel penelitian ini hanya berjenis kelamin perempuan dan tidak ada berjenis kelamin laki-laki.

b. Keterbatasan dalam metode penelitian ini dilandasi dengan jawaban benar atau salah. Sehingga dibatasi oleh peluang untuk menggali tingkat pengetahuan responden.

c. Penelitian ini hanya menggunakan kelompok treatment (perlakuan) tanpa menggunakan kelompok kontrol.

d. Edukasi hanya dilakukan satu arah ke depan sehingga pemberi edukasi kurang memperhatikan responden dan mungkin sebaliknya. Suasana edukasi dikhawatirkan dapat mempengaruhi konsentrasi. Juga diperlukan layar yang cukup luas sehingga tidak terkendala oleh tulisan yang kurang besar dari jarak jauh.

\section{SIMPULAN}

Berdasarkan hasil penelitian dapat disimpulkan bahwa edukasi efektif dalam meningkatkan pengetahuan masyarakat dalam penanganan rinitis alergi. Ada peningkatan pengetahuan secara signifikan setelah pemberian edukasi rinitis alergi (RA) dengan membandingkan antara pengetahuan sebelum diberi edukasi (pre test) dan setelah pemberian edukasi (post test) dan peningkatan lebih tinggi dicapai setelah 1 bulan sesudah pemberian edukasi (follow-up test).

\section{DAFTAR PUSTAKA}

1. Pawanka R, Bunnag C, Khaltaev N, Bousquet J. 2012. Allergic Rhinitis and Its Impact on Asthma in Asia Pacific and the ARIA Update 2008. World Allergy Organization Journal, 2012;5(3):S212.

2. American Academy of Allergy Asthma \& Immunology. 2017. Allergy Statistics (online), 2017. Tersedia di: http://www.aaaai.org/aboutaaaai/newsroom/allergy-statistics

3. Bousquet J, Schunemann HJ, Samolinski B, Demoly P, BaenaCagnani CE, Bachert $\mathrm{C}$, et al. Allergic Rhinitis and its Impact on Asthma (ARIA): Achievements in 10 years and future needs. The Journal of Allergy and Clinical Immunology, 2012;130(5):1049-1062.

4. Bousquet J, Khaltaev N, Cruz AA, Denburg J, Fokkens WJ. Allergic Rhinitis and its Impact on Asthma (ARIA) 2008 update (in collaboration with the World Health Organization, 
GA(2)LEN and AllerGen). Allergy, 2008;63(86):8-160.

5. DeGuzman DA. Guidelines for Clinical Care Ambulatory. Michigan Medicine, University of Michigan (online), 2013. Tersedia di: https://www.med.umich.edu/1 info/FHP /practiceguides/allergic/allergic.pdf

6. Scadding GK, Durham SR, Mirakian R, Jones NS, Leech SC, Farooque S, et al. BSACI guidelines for the management of allergic and non-allergic rhinitis. Clinical and Experimental Allergy, 2008;38(1):19-42.

7. Min YG. The Pathophysiology, Diagnosis and Treatment of Allergic Rhinitis. Allergy Asthma Immunol Res., 2010;2(2):65-76.

8. Peraturan Menteri Kesehatan No.919/MENKES/PER/X/1993 tentang Kriteria Obat yang Dapat Diserahkan Tanpa Resep, 1993, Jakarta.

9. Keputusan Menteri Kesehatan Republik Indonesia No. 1197/MENKES/SK/X/2004 tentang Standar Pelayanan Farmasi di Rumah Sakit, 2004, Jakarta.

10. Peraturan Menteri Kesehatan Republik Indonesia No. 35 tahun 2014 tentang Standar Pelayanan Kefarmasian di Apotek, 2014, Jakarta.

11. Katoue MG, Awad AI, Schwinghammer TL, Kombian SB.
Pharmaceutical care education in Kuwait: pharmacy students' perspectives. Pharm Pract (Granada), 2014;12(3):411.

12. Ikawati. Penyakit Sistem Pernafasan dan Penatalaksanaan Terapinya. Bursa Ilmu. Yogyakarta; 2011.

13. Lorensia A, Lisiska N. Illness Perceptions Study of Asthma Treatment Compliance in Pharmaceutical Care. Jurnal ANIMA Indonesian Psychological Journal, 2011; 26(3):184-188.

14. Lorensia A, Yulia R, Wahyuningtyas IS. Hubungan Persepsi Penyakit (Illness Perception) dengan Kontrol Gejala Asma pada Pasien Rawat Jalan. Media Pharmaceutica Indonesiana (MPI), 2016;1(2):92-99.

15. Departemen Kesehaan Republik Indonesia. Profil Kesehatan Indonesia 2008, 2009. Tersedia di: http://www.pusdatin.kemkes.go.id/reso urces/download/pusdatin/profilkesehatan-indonesia/profil-kesehatanindonesia-2009.pdf

16. Laliberté MC, Perreault S, Damestoy $\mathrm{N}$, Lalonde L. Ideal and actual involvement of community pharmacists in health promotion and prevention: a cross-sectional study in Quebec, Canada. BMC Public Health, 2012;12:192. 